\title{
1937 Redux? Reflections on Constitutional Development and Political Structures
}

\section{Citation}

Mark Tushnet, 1937 Redux? Reflections on Constitutional Development and Political Structures, 14 U. Pa. J. Const. L. 1103 (2014).

\section{Published Version}

http://scholarship.law.upenn.edu/jcl/vol14/iss5/2/

\section{Permanent link}

http://nrs.harvard.edu/urn-3:HUL.InstRepos:12918346

\section{Terms of Use}

This article was downloaded from Harvard University's DASH repository, and is made available under the terms and conditions applicable to Open Access Policy Articles, as set forth at http:// nrs.harvard.edu/urn-3:HUL.InstRepos:dash.current.terms-of-use\#OAP

\section{Share Your Story}

The Harvard community has made this article openly available.

Please share how this access benefits you. Submit a story.

\section{Accessibility}




\title{
ARTICLES \\ 1937 REDUX? REFLECTIONS ON CONSTITUTIONAL DEVELOPMENT AND POLITICAL STRUCTURES
}

\author{
Mark Tushnet \\ I. TRANSFORMATIONAL PRESIDENTS AND CONSTITUTIONAL \\ DEVELOPMENT
}

We have several ways of thinking about the Supreme Court and constitutional change. One method, exemplified often in "end of the Term" commentary, takes the cases as they come to the Court, uses rough categories such as "liberal" and "conservative" or "probusiness" and "pro-consumer" to describe the outcomes, and attempts to identify some trends in doctrine and outcomes. This method focuses almost exclusively on the Supreme Court in isolation from the rest of the government, except in occasional references to the possibility that a new Justice might affect the outcomes in some of the cases discussed. This method can generate fine-grained insights into the Court's quotidian work, but often misses the Court's role in the overall-and changing-system of government.

Another method develops models and tests them using aggregate data. ${ }^{1}$ Some models focus exclusively on the Court, worrying about the extent to which Justices decide with reference to "the law" or with reference to something else, usually described as personal values and preferences. Other models consider the Court's interaction with the President and Congress, treating the Justices as strategic actors seeking to achieve the most of whatever it is they happen to value. Like all models, those in both these types strip away a fair amount of detail and often seem unrealistic to observers who worry that too much nuance has been lost. And, sometimes the available data for aggregation match the models' variables only imperfectly, thereby reducing the depth of insight one can get from them.

William Nelson Cromwell Professor of Law, Harvard Law School.

1 LaWrence Baum, The Puzzle of Judicial Behavior 10-14 (1997) (providing a good introduction to the range of studies fitting within the approach sketched in this paragraph). 
This Article sketches a third approach, associated with a field known as "American political development" and applies ithypothetically-to explore some possibilities for constitutional development during a hypothesized second term for President Obama. This approach begins with the premise that constitutional development occurs as circumstances and structures interact. To elaborate: By "constitutional development" I mean changes in the large-scale arrangements through which political power is exercised, ${ }^{2}$ and by "structures" I mean reasonably persistent patterns of interaction among political actors, organized by reasonably persistent (but not immutable) explicit or implicit rules for deploying political power. So, for example, the rise of political parties is an example of political development in the Early Republic; the domination of our political system by two parties is an example of how rules-in this instance, the first-past-the-post system of awarding political office to the person who receives more votes than any other candidate, within geographically defined districts that elect a single representative-create structures; whether a Supreme Court vacancy occurs early or late in a President's term combines a circumstance-the timing of a death, resignation, or retirement-with a structural feature. ${ }^{3}$

This Article speculates about some possible constitutional developments in an again hypothetical second Obama term. It draws on ideas developed by political scientist Stephen Skowronek. ${ }^{4}$ Skowronek distinguishes between chronological time and political time.

"Chronological time" is the simple ticking of the clock, but taken in relation to the timing of presidential and congressional elections. Because of this relation, I refer in this Article to institutional rather than chronological time. For Congress and the Presidency, chronological and institutional time are almost identical because the Constitution-one of our structural rules-requires that elections occur at

2 My concern is with constitutional development, not doctrinal development, and the Supreme Court comes into my sights only when its role in organizing and distributing political power becomes relevant to the argument.

3 For present purposes I simply assume, as the empirical evidence weakly suggests, that Justices do not time their departures strategically. For one study, see Christopher J. W. Zorn \& Steven R. Van Winkle, A Competing Risks Model of Supreme Court Vacancies, 1789-1992, 22 POL. BEHAV. 145, 145 (2000) (concluding that "[J]ustices who retire do not generally do so for expressly political reasons"). But see Timothy M. Hagle, Strategic Retirements: A Political Model of Turnover on the United States Supreme Court, 15 POL. BEHAV. 25, 25 (1993) (finding "an identifiable political element relating to the timing of retirements from the Court").

4 See Stephen Skowronek, The Politics Presidents Make: Leadership From John ADAMS TO BILL CLINTON (1993). 
fixed chronological intervals. ${ }^{5}$ But, chronological and institutional time differ for the Supreme Court, because of the irregularity and unpredictability with which Justices replace each other. That irregularity interacts with the complex relation between institutional time for the President with a four-year term potentially renewable once and the Senate with one-third elected every two years. Because the President's institutional time differs from the Senate's, the nomination and confirmation process can change within a single President's term, and the characteristics of that process will affect the replacement of one Justice by another in unpredictable ways. ${ }^{6}$

"Political time," for Skowronek, refers to the relation between a President and his or her predecessors and successors. Skowronek identifies several presidential types, defined with reference to political time. For my purposes, only one is of interest. Some Presidents, Skowronek argues, are "transformative" or "reconstructive." 7 Such Presidents see themselves as repudiating the general policy paths marked out by their immediate predecessors and setting out on quite different paths. In addition, they devise new institutions of government, or alter existing ones, to generate and sustain new constituencies that will enduringly support the President, at least in part because of the new policies the President has put in place. ${ }^{8}$ Transformation is of course not instantaneous, but emerges-if it does-as the President's policies are implemented, new or modified institutions begin operating, and new constituencies of political support develop.

For present purposes I treat President Obama as a potentially reconstructive or transformational President. That he positioned himself against an exhausted set of policies associated with a series of Presidents seems uncontroversial. That he aspired to a large-scale

5 The difference between chronological and institutional time with respect to elections can be seen in parliamentary systems, which generally allow the executive head of government to decide when, within some fixed time span, to call an election.

6 For example, on the assumption animating this Article, that President Obama is reelected, whether a Supreme Court vacancy will occur during his second term is entirely contingent, but whether he will have to get a replacement Justice confirmed by a Senate with a Republican or a Democratic majority is the product of the difference between institutional time for the President and the Senate. (I deal with issues arising from the possibility of a minority party filibuster below, see infra text accompanying note 17.)

7 SKOWRONEK, supra note 4 , at 36-42.

8 Importantly, reconstructive Presidents may see themselves in this way, but they need not present themselves as such in their initial campaigns. Usually all they must do is say that they are true alternatives to a prior presidency or series of presidencies whose policies can be presented as having been exhausted. A classic example is Franklin D. Roosevelt ("FDR"), whose 1932 campaign included strong commitments to balancing the budget, abandoned shortly after FDR took office. 
shift in policy direction is of course more controversial, for several reasons. Dramatic shifts in policy direction have not (yet) occurred. In addition, some elements of shifts Obama offered as a candidate appear to have been abandoned (for now), with climate change legislation being the primary example. And, the President's major policy initiative, one healthcare provision, ended up rejecting structures like a single-payer system or payment of all medical costs by the government that would have been dramatic changes, in favor of a complex structure that accepted much of the core of private control of healthcare insurance.

Even with these cautions, I think it interesting to think of President Obama as reconstructive or transformational. Shift attention from policies to structures, and we can see some features associated with transformational presidencies. For example, as a candidate Obama creatively exploited the new social media far more effectively than anyone had previously done. ${ }^{9}$ He generated a large amount of financial support from what (adapting a term from Professor Richard Hasen) I call "microfinancing," a steady flow of small-scale but often repeated contributions. ${ }^{10}$ He also organized the so-called "ground game"-the techniques of person-to-person appeals and get-out-thevote efforts that political scientists have shown to be enormously effective $^{11}$-through the new social media. ${ }^{12}$

A second example is the political effect of the Affordable Care Act. Even though the Act is under a constitutional cloud as I write in April 2012, some of its components have already been implemented, and the beneficiaries-families with children under the age of twentysix covered by their parents' health insurance, and those with prior medical conditions that previously would have disqualified them from obtaining health insurance-can be counted as likely supporters of President Obama in the next election and of the Democratic Party thereafter. ${ }^{13}$ If fully implemented in 2014, the Affordable Care Act

9 David Carr, How Obama Tapped into Social Networks' Power, New YORK Times, Nov. 9, 2008.

10 See Rick Hasen, Senator Obama and the Decision to Opt Out of Public Financing, Election L. BLOG (May 27, 2008, 11:44 am), http://electionlawblog.org/archive.0s/010905.html (referring to "micro-donors").

11 See Donald P. Green \& Alan S. Gerber, Get Out the Vote: How to Increase Voter Turnout (2004) (summarizing the research findings).

12 See Robert Paul Wolff, The Ground Game, The Philosopher's Stone, (Dec. 7, 2011, 3:59 am), http://robertpaulwolff.blogspot.com/2011/12/ground-game.html (describing the Obama ground game in 2008).

13 Some qualifications: The Great Recession's continuing economic effects may weaken this effect, as does the possibility that the Supreme Court would find the Affordable Care Act's core individual-mandate provision unconstitutional and inseverable from the remainder of the statute, including the provisions already in effect. 
might have political effects similar to that of the Social Security system, tying a large group of beneficiaries (and voters) to the party responsible for its enactment. ${ }^{14}$ Perhaps the Democratic Party should embrace the term "Obamacare," devised by Republicans as a derogatory term-at least if the Affordable Care Act is fully implemented.

\section{STRUCTURES OF RESISTANCE TO TRANSFORMATIONAL OR RECONSTRUCTIVE PRESIDENTS}

Continuing with the assumption that President Obama is a transformational or reconstructive President, we must consider the next steps in Skowronek's argument. Transformational Presidents inevitably face opposition. They may have defeated the old order in a single election, but differences in institutional time mean that politicians supporting that order remain in office, with some-sometimes significant-political resources. Transformational Presidents hope to overcome that opposition as time passes and institutional time is displaced by political time.

But, Skowronek argues, that hope becomes increasingly difficult to realize because of what he calls "institutional thickening." ${ }^{15}$ Institutional thickening describes the institutional and structural legacy of the old order. Transformational Presidents are followed by others who consolidate that President's innovations, or accept them as part of the environment within which the successor Presidents must work. The transformational or reconstructive President's institutional innovations remain in place, and provide continuing support for that President's programs-even after the transformational presidency and its successors have exhausted the possibilities presented by their innovations.

I have already alluded to one example of institutional thickening - the political support generated by the adoption of Social Security and Medicare. Today politicians who believe it important to confront what they regard as the serious fiscal consequences of those programs understand that the programs' current beneficiaries strongly support the programs in their current form and would punish any politician who threatened to alter them substantially. Politicians respond by developing reform programs that insulate current

14 Here the major qualification is that the Affordable Care Act might have long-term fiscal implications that would be politically problematic. But, those implications might be irrelevant to a politician with a time-horizon of one or two decades. And, I suspect, all Presidents have such a time horizon.

15 SKOWRONEK, supra note 4 , at 56. 
beneficiaries from changes, even though doing so can significantly reduce the fiscal benefits the reforms hold out.

The example of Social Security suggests another, broader example of institutional thickening. Franklin D. Roosevelt's ("FDR") presidency, and those of his successors, such as John F. Kennedy and Lyndon Johnson, created a politics of interest groups, theorized by some as political pluralism and by others as public choice theory. The interest groups benefited from and provided support for a wide range of policies and institutions associated with the New Deal and the Great Society. They also contributed to the rise of what political scientists call the "iron triangle" 16 of policy-making, the legs of which are the interest groups, the relevant executive bureaucracies, and the relevant congressional committees. Notably, the executive at the highest level-the President-is not part of the iron triangle. A reconstructive President can break some of the iron triangles in place when he or she takes office. But, obviously, doing so takes more political effort than would be required if the triangles did not exist or were made of paper rather than iron. The iron triangles of the late twentieth century were part of the institutional thickening to which Skowronek refers.

As chronological time passes, then, it becomes increasingly difficult for a transformational or reconstructive President to succeed in his or her ambitions. I offer some examples of how institutional thickening manifested itself during the Obama presidency.

The first is constitutional hardball, which I have defined as the development of practices that violate previously well-understood and accepted ways in which members of political parties who disagreed on matters of policy conducted their debates-and fights-over policy development. ${ }^{17}$ Putting aside assertions about a decline in civility within Congress, which may not rest on accurate descriptions of past practices, we can see constitutional hardball in the state of play in connection with presidential nominations. Republicans played constitutional hardball in filibustering nominations to fill positions at the

16 See B. Dan Wood \& Richard W. Waterman, Bureaucratic Dynamics: The Role of BUREAUCRACY IN A DEMOCRACY 18 (1994).

17 Mark Tushnet, Constitutional Hardball, 37 J. Marshall L. Rev. 523 (2004). Note that the publication date precedes the Obama presidency. See Eric A. Posner \& Adrian Vermeule, Constitutional Showdowns, 156 U. PA. L. REv. 991, 991 (2008), for related discussions referring to "showdowns" or constitutional disagreements between branches of government often ending in litigation or settlement that establish a non-judicial precedent; see also Sanford Levinson \& Jack M. Balkin, Constitutional Crises, 157 U. PA. L. REv. 707 (2009) (describing the use of the word "crisis" as a political tool to gain power or sway with the American public). 
National Labor Relations Board and the Consumer Financial Protection Bureau; such positions had to be filled for those agencies to have the authority to make legally binding decisions. President Obama replied with his own hardball, an aggressive interpretation of the constitutional provision authorizing him to make appointments during congressional recesses. ${ }^{18}$

A feature of constitutional hardball is that each side contends that the other breached the relevant implicit understandings first. ${ }^{19}$ The prior breach then is said to have destroyed the implicit understandings already, thereby taking the sting out of the charge that one is breaching taken-for-granted norms. This feature of constitutional hardball feeds into another form of institutional thickening, the dramatic ideological polarization of the political parties over the past decade. Political scientists measure this polarization in various ways, and offer diverse accounts of its origins and depth, but there appears to be general agreement that the polarization in Congress is wider than it has been in many decades, and perhaps in a century or more. $^{20}$

Perhaps ideological polarization in itself is not a structural feature of our government, as I have defined structures earlier. To make it structural, one would need an argument supporting the proposition that polarization has become substantially self-reinforcing, so that once in place it is difficult to reduce. I have suggested that constitutional hardball's characteristic of generating "you did it first" disputes might contribute to this self-reinforcement, but I am reasonably confident that there are other and more important contributors. The next paragraphs only sketch some possibilities that I think deserve exploration along with others.

One candidate for providing structural support for polarization is the overall system of campaign finance. The overall system includes both the microfinancing I have mentioned and large-scale expenditures by nominally independent groups. Microfinancing contributes to polarization because of the widely observed phenomenon of the "bubble," or, put less metaphorically, the tendency of people to use social media to interact with and learn from others who already share

18 For the Obama administration's official legal defense of its interpretation, see Lawfulness of Recess Appointments During a Recess of the Senate Notwithstanding Periodic Pro Forma Sessions, 36 Op. O.L.C. 1 (2012).

19 I note that I did not understand this as a feature of constitutional hardball when I developed the concept.

20 See An Update on Political Polarization (through 2011), Voteview Blog (Jan. 30, 2012), http://voteview.com/blog/?p=284 (concluding that "Congress is now more polarized than at any time since the late [nineteen] th century"). 
their own views. The bubble, it is generally believed, contributes to polarization by amplifying and making more extreme the views people hold when they enter the bubble. ${ }^{21}$ Microfinancing occurs within the bubble, and small contributors are then flooded with communications from those to whom they have given money and, importantly, by others of a similar political persuasion.

Large-scale independent expenditures affect polarization as well. Such expenditures allow candidates to run a two-track campaign. The candidate's own expenditures support high-minded appeals to the public interest, while the independent expenditures allow attacks on the candidate's opponents. ${ }^{22}$ Attacks motivate supporters more effectively than positive ads, ${ }^{23}$ but when they emanate from independent groups, the positive effect on turning out supporters comes without a backlash against the candidate.

Notably, the campaign finance system has been shaped at least in part by the Supreme Court, and in particular by the Court's insistence-correct, in my view-that truly independent expenditures receive serious First Amendment protection. ${ }^{24}$ And, this fact brings into view another source of opposition to a transformational President's efforts-institutional time as well as institutional thickening.

21 The standard citation in the legal literature on this is CASS SunSTEIN, REPUBLIC.COM (2001); see also Eric Lawrence, John Sides \& Henry Farrell, Self-Segregation or Deliberation? Blog Readership, Participation, and Polarization in American Politics, 8 PERSP. ON POL. 141, 141 (2010) (concluding that "blog readers gravitate toward blogs that accord with their political beliefs," that "those who read left-wing blogs and those who read right-wing blogs are ideologically far apart," and that "blog readers are more polarized than either non-blogreaders or consumers of various television news programs, and roughly as polarized as $\mathrm{U}$ [nited] S[tates] senators").

22 This argument is predicated on what I believe is coming to be the conventional wisdom, that independent expenditures are only nominally independent of the candidate's own campaign. Journalists have emphasized, for example, how major independentexpenditures organizations are staffed by people formerly closely associated with an individual candidate or his or her campaign.

23 On the effects of attack ads, see JoHn G. GEer, In DEFENSE Of NEGATIVITY: ATTACK Ads in PRESIDENTIAL CAMPAIGNS 142 (2006) ("[N] egativity could 'augment turnout by arousing the voter's enthusiasm for his or her preferred candidates or by increasing the degree to which the voter cares about the outcome of the election." (quoting Steven E. Finkel \& John G. Geer, A Spot Check: Casting Doubt on the Demobilizing Effect of Attack Advertising, 42 AM. J. POL. SCI. 573, 577 (1998))).

24 In brief: The First Amendment should be interpreted to allow people to hire others to get the views they hold across more effectively than they themselves can, which is simply a description of independent expenditures. And, the mere fact that a person makes a judgment that the most effective way of assisting a favored candidate's campaign is to track or supplement what the candidate's campaign is itself saying should not be problematic. The difficulty, of course, is that no one thinks that a large portion of nominally independent expenditures are really independent. 
Structurally, and because of institutional time, early in a transformational President's term, the Supreme Court is almost guaranteed to be skeptical about the President's initiatives, and to be receptive to plausible constitutional challenges to those initiatives. Most of the Justices in place when the reconstructive or transformational President arrives will have been appointed by Presidents whose policies the new President repudiates and seeks to change. By and large they will have been chosen because of their "soundness"-or because they have "mainstream" views-which is to say, because they think about the Constitution in ways congenial to the appointing President's general orientation. And finally, over the preceding years these Justices will have developed a set of doctrines that will provide substantial legal resources for credible legal arguments against the transformational President's initiatives. ${ }^{25}$

A reconstructive or transformational President is likely to face resistance from the Supreme Court, at least in connection with programs that can be brought under constitutional scrutiny. And here too a form of institutional thickening might matter. Over the past century the grounds for constitutional objection have expanded and the occasions on which the courts are precluded from addressing constitutional questions on the merits have been reduced. For example, the Affordable Care Act's individual-mandate provision will become legally binding (if the statute survives constitutional challenge) only in 2014, but the idea that the courts should abstain from addressing the constitutional challenges in cases brought in 2011 quickly fell by the wayside. ${ }^{26}$ Put in general terms: A reconstructive or transformational President will advance many new programs; many of those initiatives will be subject to credible constitutional challenges predicated on the doctrinal structure developed by the Supreme Court over the preceding decades; and, many of those challenges will in fact be presented to the Supreme Court. ${ }^{27}$

25 We might think of this as the way in which institutional thickening takes place within the Supreme Court. The thickening is lessened by the possibilities of doctrinal change and distinguishing or overruling adverse precedents.

26 Another form of institutional thickening may matter as well-the development of what political scientist Charles Epp calls a "support structure" for constitutional litigation. For Epp's exposition, see CHARLES R. EPP, THE Rights REVOLUTION: LAWYERS, ACTIVISTS, AND SUPREME COURTS In COMPARATIVE PERSPECTIVE (1998). On the extension of that support structure from the liberal to the conservative side, see STEPHEN M. TELES, THE RISE OF the Conservative legal Movement: The Battle for the Control of the LaW (2008).

27 Nothing in the argument I have made rests on the idea that the Justices in place are merely doing the bidding of the Presidents who appointed them, or of that President's party. The argument is that they sincerely hold a way of thinking about the Constitution 


\section{CONFRONTATION AS THE RESUlt OF ATTEMPTED TRANSFORMATION AND RESISTANCE}

This Article's title suggests one possible outcome of attempted transformation and resistance resulting from institutional timeconstitutional crisis. The constitutional confrontation of 1937 had the features I have described: FDR, a reconstructive or transformational President, pursuing novel policy initiatives, a Supreme Court shaped by repeated appointments designed to entrench a constitutional vision inconsistent with FDR's, constitutional doctrinesespecially the distinction between actions with direct and indirect effects-available for use to obstruct FDR's initiatives. I need not rehearse the familiar details of FDR's effort to rein in the Court through expanding its membership, nor the manner of the confrontation's resolution through repeated electoral successes, which gave him the opportunity to appoint enough new Justices to change the Court.

The similarity between FDR's political environment and Obama's-a potentially transformative President confronting resistant elements of a prior constitutional order-suggests the possibility of a similar outcome, that is, another constitutional crisis. The Roberts Court might invalidate the Affordable Care Act, or it might take the side of congressional Republicans in some important plays of hardball, such as the President's recent recess appointments. One can imagine President Obama in his second term finding himself shackled by the Court's decisions and seeking to devise ways of effectively defying the Court. Yet, there are enough differences between FDR's situation and Obama's to justify the question mark in the Article's title.

Right on the surface, the tools a President has to confront the Court are quite limited. The failure of FDR's Court-packing plan has, in my judgment, created or perhaps confirmed a constitutional convention that the Court's size cannot be altered merely to achieve political goals. ${ }^{28}$ No other tools seem readily available, although one can

compatible with what were regarded as sound or mainstream views when they were appointed, and that they were appointed because they held those views.

28 I put the convention in these terms because prior changes in the Court's size sometimes occurred in settings where the political implications of doing so were clear, and sometimes where political considerations motivated the changes, but the changes were accompanied with plausible "good government" reasons for the changes. (Indeed, FDR dressed up his proposal in "good government" terms, presenting the Court-packing plan as a method of addressing purported difficulties the nine-member Court had in handling its ca- 
imagine a President reviving a rhetoric of popular constitutionalism as a way of reshaping public views about the Court, or selecting new nominees for vacancies as they occur on the basis of their acceptance of some version of popular constitutionalism. ${ }^{29}$

Looking to the deeper level identified by the idea of constitutional development, we can see some important structural features that reduce the possibility of confrontation and crisis. First, institutional thickening means that even continued electoral success does not imply policy success. The polarization that produces thickening in some areas has several effects. Constitutional hardball has changed the taken-for-granted rules about filibusters, for example. Perhaps Senate Democrats would change the filibuster rules, but the Senate's rules contain enough provisions that provide opportunities for obstructionism and delay that filibuster reform is unlikely to reduce this aspect of institutional thickening. ${ }^{30}$ Party structures were different during the New Deal than they are now. Then political parties were clearly coalitions among ideologically disparate groups. There were conservative and liberal Republicans, and conservative and liberal Democrats. That gave FDR and his congressional allies some room for political maneuver. Political polarization has eliminated that room for maneuver.

Relatedly, many of the New Deal's policy initiatives, such as establishing a national minimum wage, had deeper support in the public than at least some provisions in the Affordable Care Act. That meant that FDR could reasonably expect substantial public support for some sort of response to the Supreme Court. ${ }^{31}$ It seems to me unlikely that President Obama could have a similar expectation. So, taking all these matters into account and anticipating that institutional thickening will make constitutional confrontation with the Supreme Court futile, President Obama might forgo the opportunity for that kind of confrontation.

Turning from the possibilities open to the President to those available to the Supreme Court: Institutional thickening means that

seload.) See Justin Crowe, Building the Judiciary: LaW, Courts, AND the Politics of INSTITUTIONAL DEVELOPMENT (2012).

29 For myself, I doubt that President Obama would be inclined to take even these modest steps.

30 For my brief prior comments on this question, see Mark Tushnet, Legal Reasoning in Congress, 95 IOWA L. REv. BulL. 81, 85-87 (2010).

31 Barry Cushman pressed this point on me, presenting it as a circumstantial fact about the late 1930s. I have tried to link the differences in public support for presidential initiatives to structural features, but perhaps my argument is forced, and the public opinion constraint is simply circumstantial and not structural. 
there is no need for a Court embodying the values of a displaced constitutional order to confront the President, because it can rely on the institutional residue of that order elsewhere to take on the President. In 1937 Republicans who opposed FDR had few political resources to deploy. The President's party had massive majorities in both houses of Congress, and even taking the coalitional nature of the parties in the 1930s into account, FDR's opponents could do little to obstruct his initiatives, especially given the popularity of many of those initiatives. $^{32}$ The Supreme Court was the only institutional location in which the older order retained enough power to accomplish anything. The situation today is quite different. Political polarization, the new understandings about filibustering, and the relative narrowness of the margins of support for the President (and, at least in 2011-2013, Republican control of the House of Representatives) make it possible for the President's opponents to block his initiatives.

Of course those same conditions raise other possibilities. A President finding it impossible to move his initiatives through Congress might turn to what Elena Kagan called "presidential administration." ${ }^{33}$ Presidential administration is a structural development that responds to institutional thickening, specifically to the political polarization that makes it difficult for Congress to enact presidential initiatives. It involves Presidents using their executive powers-whether inherent or broadly delegated to them by Congress-to advance their distinctive initiatives. ${ }^{34}$ Presidential administration makes the President the "first mover" in policy implementation, and the polarization that makes presidential administration attractive to Presidents means that Congress will be unable to counter his "first moves."

But, presidential administration could be only another feature of the way in which institutional thickening might produce constitutional crisis. The President will claim that presidential administration

32 After the 1936 elections there were seventy-five Democrats in the Senate, seventeen Republicans, and four others; 333 Democrats in the House, eighty-nine Republicans, and thirteen others. See Composition of Congress, by Political Party, 1855-2013, INFOPLEASE.COM, http://www.infoplease.com/ipa/A0774721.html (last visited Apr. 9, 2012) (setting forth the breakdown of the composition of Congress by political party from 1855 through the present).

33 Elena Kagan, Presidential Administration, 114 HARV. L. REV. 2245, 2246 (2001).

34 See id. at 2282-84 (noting examples of presidential administration during the years of Clinton's presidency, such as initiatives on smoking and parental leave in which President Clinton strongly associated the White House with yet-to-be-adopted administrative regulations). In 2012 President Obama announced his intention to use executive power to implement as much of his jobs program as could be done without new legislation. This is as clear an example of presidential administration as can be imagined, and came in response to partisan polarization. 
is lawful, but such claims might be controversial. Take presidential administration in the form of exercising assertedly delegated power. The President's opponents will almost certainly contend that the prior delegations do not in fact authorize the steps the President has taken, particularly when the President takes those steps because he was unable to obtain express contemporaneous congressional authorization for them. As I noted in connection with President Obama's aggressive use of the recess appointment power, his opponents might go to court to challenge presidential administration. ${ }^{35}$ And, the courts might agree with his opponents.

If that occurs, a confrontation that is at its core between the President and his opponents in Congress could become a confrontation between the President and the Supreme Court. And, again, there might be little the President could do in response. Put overly crudely: The very fact that the President's opponents in Congress can impede his initiatives means that they would be able to block any action he might hope to take against the Supreme Court.

That leaves the mechanism that FDR actually used to bring the Court into the New Deal-the power to appoint new Justices. And here, a development on the border between circumstance and structure comes into play. Advances in medicine mean that people in general have longer life expectancies than in the past. Presidents have understood the implications for life-tenured appointments: Appoint relatively young judges. Doing so will make it more difficult for future Presidents to use FDR's mechanism. ${ }^{36}$

\section{CONCLUSION}

In this Article I have sketched a way of thinking about the Supreme Court and the other branches of our government. Readers may well be skeptical about many of my specific assertions. Most obviously, I know from conversations in which I have offered similar

35 I think that the idea of presidential administration can be extended to cover exercises, particularly aggressive ones, of the recess appointment power, but I do not think that anything turns on whether those exercises are described as examples of presidential administration.

36 An anecdotal indication of the phenomenon: Justice John Paul Stevens retired at age 90. On January 21, 2017, the day after a hypothetically reelected President Obama leaves of fice, Justice Antonin Scalia - the oldest of the Justices on the Court in 2012 who were appointed by Republican Presidents—and Justice Anthony Kennedy, the next oldest, will be in their early 80s. Of course both men might leave the Court between 2013 and 2017, but the anecdotal point is that increasing life expectancy might mean that a Democratic President elected in 2012 might not have the opportunity to use the mechanism available to FDR. 
sketches that many readers will be skeptical about the assertion that President Obama is, or seeks to be, a reconstructive or transformational President. But, there are other assertions that might be met with skepticism-about whether institutional thickening has occurred, or what the characteristics of institutional thickening are, or what the implications of institutional thickening might be.

As a scholar I am not deeply invested in any of these assertions, and so am not bothered by skepticism of the sort I have described. As a scholar I do want to suggest that thinking about the Supreme Court and constitutional development in the manner I have sketched here is likely to be productive. ${ }^{3}$

37 So, for example, I would be happy to see someone develop an argument about the possible course of constitutional development were President Obama to be what Skowronek calls a "preemptive" President. Such Presidents operate within the assumptions of a political regime created by a reconstructive or transformative President of the other major party (Dwight Eisenhower vis-à-vis Franklin Roosevelt, Bill Clinton vis-à-vis Ronald Reagan, for example-and, perhaps, Barack Obama vis-à-vis Reagan as well). I would be interested as well in seeing an argument about a hypothesized President Romney, who would be what Skowronek calls a President engaged in a politics of "articulation" or a "disjunctive" President. Both types are fully committed to a predecessor's reconstructive efforts, and both seek to make a name for themselves by extending the predecessor's efforts. They differ in that the latter take office when many of the predecessor's initiatives have taken root and have to some degree generated their own difficulties-when the existing system is, in Skowronek's terms, "vulnerable" rather than "resilient." For Skowronek's description of these other categories, see SKOWRONEK, supra note 4, at 39-45. 